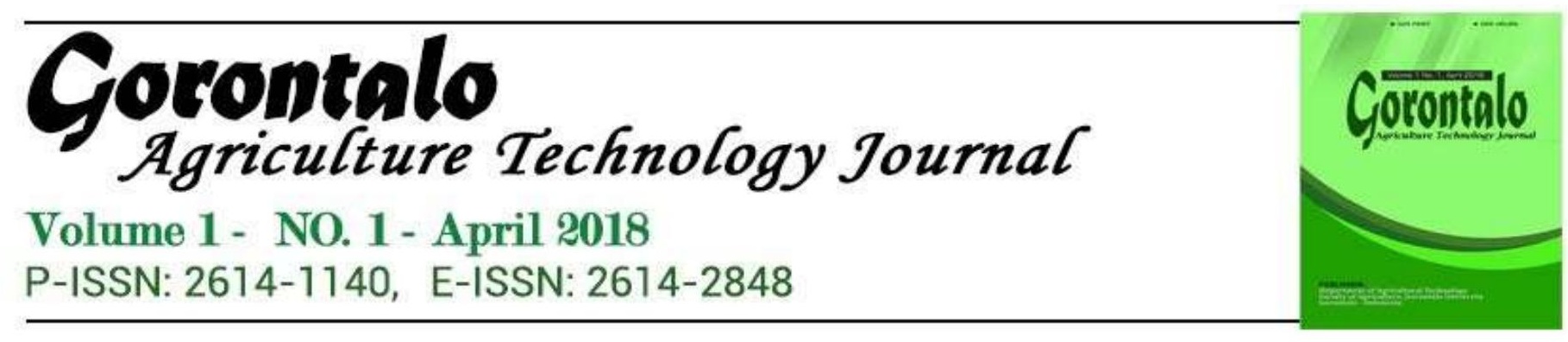

\title{
Pengaruh Penambahan Tepung Pisang pada Pembuatan Kerupuk
}

Novita Yasin 11

1 Teknologi Hasil Pertanian Fakultas Pertanian Universitas Gorontalo email: novitayasinthp12@gmail.com

\begin{abstract}
crackers is the product dry food that has been known in Indonesia, food spread almost to all corners of Indonesia and favored by all walks of life. one of the type of banana that can be used as flour banana is banana kepok. flour banana made of bananas still raw but that was old enough. utilization of flour bananas in the substitution making food items are expected to reduce the dependence of wheat flour. the purpose of penelitin this is to obtain the formulation of the appropriate for the manufacture crackers with a basic materials flour banana kepok and to know the revenue panelists to the characteristics crackers flour banana kepok. this study was conducted in the laboratory technology agricultural University gorontalo and laboratory technology agricultural Polytechnic gorontalo. this research was conducted in the form of the design of randomized complete (RAL) consisting of 3 treatment and 3 times replicates. parameters conducted in this study is water content, ash content, level of carbohydrate and test organoleptic. treatment of research influential very real at the level of carbohydrate, ash content and water content. based test results organoleptic, treatment is best a2 (50\% tapioca starch $+50 \%$ of flour banana kepok) with a score of aroma 2,9 (somewhat like), a sense of 3,0 (like), texture 2,8 (somewhat like) and the color of 2,7 (somewhat like) grading carbohydrates $8,83 \%$, water content $8,48 \%$ and ash content $2,42 \%$.
\end{abstract}

Keywords : crackers, flour banana kepok, banana kepok, test organoleptic, test proximate.

\section{PENDAHULUAN}

Kerupuk adalah produk makanan kering yang telah dikenal di Indonesia, makanan ini tersebar hampir ke segenap pelosok Indonesia serta digemari oleh semua lapisan masyarakat. Pemasaran kerupuk berkembang tidak hanya didalam negeri, tetapi juga di luar negeri seperti Nederland, Suriname, Amerika, Jepang, Hongkong, Singapura dan lain-lain (Wiriano, 1984).

Salah satu jenis pisang yang dapat dijadikan tepung pisang adalah pisang kepok. Tepung pisang dibuat dari buah pisang yang masih mentah namun yang sudah cukup tua. Tepung pisang banyak dimanfaatkan sebagai campuran pada pembuatan roti, cake, kue kering, campuran tepung terigu, dan campuran makanan bayi. Pada dasarnya semua jenis buah pisang mentah 
dapat diolah menjadi tepung, tapi warna tepung yang dihasilkan bervariasi, karena dipengaruhi oleh tingkat ketuaan buah, jenis buah dan cara pengolahan. Baik pisang muda, pisang tua atau yang masak bisa dijadikan tepung, tetapi buah yang muda menuju tua lebih cepat pembuatannya dikarenakan kadar air dan gulanya rendah, sehingga cepat dalam proses pengeringannya. Sedangkan yang masak agak lama, karena kadar patinya sudah berkurang. Biasanya buah yang masak keadaannya basah oleh kadar gula yang tinggi, sehingga memerlukan pengeringan yang lebih lama (Soedjono dan Nuryani, 2001).

Tepung pisang tersebut berfungsi sebagai pengganti (subtitusi) atau bahan campuran dengan tepung tapioka. Subtitusi tepung pisang terhadap tepung tapioka pada pembuatan kerupuk berkisar $10-100 \%$, tergantung dari jenis yang dibuat. Pemanfaatan tepung pisang dalam subtitusi pembuatan bahan makanan tersebut diharapkan dapat mengurangi ketergantungan terhadap tepung terigu. Ketergantungan terhadap salah satu pangan pokok khususnya terigu, menuntut masyarakat untuk menggali potensi pangan lokal yang ada disetiap daerah. Pisang (Musa paradisiaca) sebagai salah satu tanaman buah-buahan mempunyai potensi besar diolah menjadi tepung sebagai substitusi tepung terigu.

Karakteristik dari kerupuk yang disukai oleh konsumen memiliki volume pengembangan yang baik, kerenyahan yang baik dan penampakan menarik. Volume pengembangan kerupuk dipengaruhi oleh kadar amilopektinnya, dimana tapioka memiliki amilopektin yang tinggi. Pati tersebut tidak larut dalam air, tetapi jika ditambahkan air dan dilakukan pemanasan akan menyerap air dan mengembang, proses tersebut disebut gelatinisasi.

\section{METODE PENELITIAN}

\subsection{Alat dan Bahan}

Alat yang digunakan dalam pembuatan kerupuk adalah baskom, pisau, blender, pengaduk, timbangan,loyang, panci pengukus, kompor gas, oven.

Bahan yang digunakan adalah tepung tapioka, buah pisang kepok kuning, air, tepung terigu, garam, bawang putih, gula pasir, soda kue, dan penyedap rasa.

\subsection{Metode Penelitian}

Rancangan percobaan dalam penelitian ini menggunakan RAL (Rancangan Acak Lengkap) dengan tiga perlakuan dengan tiga kali ulangan. Apabila hasilnya berbeda nyata maka akan dilakukan uji beda nyata terkecil (BNT) sebagai uji lanjutan. Perlakuan dalam penelitian ini adalah sebagai berikut :

A1 : $75 \%$ gr Tepung tapioka $+25 \%$ gr Tepung pisang kepok

A2 : 50\% gr Tepung tapioka $+50 \%$ gr Tepung pisang kepok

A3 : $25 \%$ gr Tepung tapioka $+75 \%$ gr Tepung pisang kepok 


\subsection{Prosedur Penelitian}

\section{Pembuatan Tepung Pisang}

Sebelum diolah menjadi tepung, pisang kepok kuning yang tua tetapi belum masak dengan kulit yang masih hijau dan keras dan direbus selama 5 menit kemudian dikupas dan dibersihkan dari bijinya. Setelah itu pisang yang sudah bersih direndam dalam larutan asam sitrat 1,5g/L selama 15 menit lalu ditiriskan dan diiris tipis menggunakan alat pengiris manual, sehingga berbentuk potongan dengan ukuran kurang lebih $1 \times 0,5 \mathrm{~cm}$ setelah itu dilakukan pengeringan menggunakan cabinet dryer selama 6 jam dengan suhu $60^{\circ} \mathrm{C}$. Tanda sudah kering adalah jika gaplek pisang mudah dipatahkan dengan kadar air sekitar 6-10\% dan selanjutnya dihancurkan dengan blender dan diayak dengan kehalusan 80 mesh.

\section{Pembuatan Kerupuk}

Tepung pisang disiapkan sesuai dengan perlakuan. Kemudian tepung pisang dicampurkan denga tepung tapioka sesuai dengan perlakuan. Dicampurkan dengan bawang putih halus,MSG, Garam, Gula, Soda kue, Tepung Tapioka dan Air. Dilakukan pengukusan selam 30 menit dengan suhu $100^{\circ} \mathrm{C}$ kemudian didinginkan, selanjutnya dilakukan pemotongan. Setelah itu digoreng dengan minyak panas lalu diangkat dengan mengunakan tiris.

\subsection{Parameter Pengamatan}

\section{Kadar Air Basis Kering (Sudarmadji et al.1984)}

Pengukuran kadar air sampel dilakukan dengan proses pengeringan. Prosedur kerja pengukuran kadar air sebagai berikut ;

1. Cawan kosong dan tutupnya dikeringkan dalam oven selama 15 menit.

2. Ditimbang dengan cepat kurang lebih 5 gr sampel yang sudah dihomogenkan dalam cawan.

3. Sampel dimasukkan dalam cawan dan dimasukkan dalam oven selama 3 jam.

4. Cawan didinginkan 3-5 menit. Setelah dingin bahan ditimbang.

5. Bahan dikeringkan kembali dalam oven 30 menit sampai diperoleh berat konstan atau tetap.

6. Kadar air dihitung dengan rumus ;

$$
\% \text { Kadar Air : } \frac{\text { berat awal-berat akhir }}{\text { berat awal }} \times 100 \%
$$

\section{Kadar Abu (Sudarmadji et al. 1984)}

Pertama Kurs porselen dioven selama 15 menit untuk menghilangkan kandungan air yang ada pada kurs porselen. Kemudian dieksikator selama 5 menit untuk menstabilkan kelembabab $(\mathrm{RH})$. Kurs porselen ditimbang sebagai a gram dan ditambahkan 3-10 gram bahan. Kemudian dimasukkan ke dalam tanur untuk proses pengabuan. Nyalakan tanur dan dilakukan pengaturan suhu pada skala 30 - 40 (menunjukkan suhu $300-400{ }^{\circ} \mathrm{C}$ ) selama 1 jam atau sampai asapnya hilang. Hal ini dilakukan agar porselen tidak retak atau pecah apabila suhu langsung dinaikkan, selain itu hal ini juga bertujuan untuk 
menghilangkan senyawa-senyawa organik yang terdapat pada bahan. Selanjutnya suhu dinaikkan sampai skala 60 - 80 (menunjukkan suhu $600-800{ }^{\circ}$ C) selama 4 jam, dimana waktu dan suhu tersebut adalah waktu dan suhu yang optimal untuk proses pengabuan

\section{Analisis karbohidrat (Sudarmadji et al, 1984)}

Rumus \% karbohidrat $(\mathrm{g} / 100 \mathrm{~g})=100-($ protein+abu+air)

\section{Uji Organoleptik (Rahayu, 2011)}

Ujiorganoleptik yang dilakukan meliputi tekstur, warna, aroma, dan rasa dari kerupuk pisang kepok. Metode pengujian yang dilakukan metode hedonic (ujikesukaan). Sampel disajikan secara acak pada panelis, Kemudian panelis diminta untuk memberikan nilai menurut tingkat kesukaan. Skala hedonic yang digunakan yaitu :

$$
\begin{aligned}
& 1=\text { Sangat tidak suka } \\
& 3=\text { Tidak suka } \\
& 3=\text { Agak suka } \\
& 4=\text { Suka } \\
& 5=\text { Sangat suka }
\end{aligned}
$$

\section{HASIL DAN PEMBAHASAN}

\subsection{Kadar Karbohidrat}

Karbohidrat merupakan sumber kalori utama bagi hampir seluruh penduduk dunia. Khususnya bagi penduduk Negara yang sedang berkembang. Karbohidrat juga mempunyai peranan penting dalam menentukan karakteristik bahan pangan misalnya rasa, warna, tekstur, dan lain-lain (Winarno, 2004). Kisaran karbohidrat produk kerupuk pisang yang dihasilkan adalah 8,83$13,35 \%$. Kadar karbohidrat terrendah adalah kerupuk dengan perlakuan $75 \%$ tepung tapioka dan 25\% tepung pisang kepok dengan nilai sebesar 8,83\%, sedangkan kadar karbohidrat tertinggi yaitu perlakuan tepung tapioka 25\% dan $75 \%$ tepung pisang kepok dengan nilai sebesar 13,35\%.

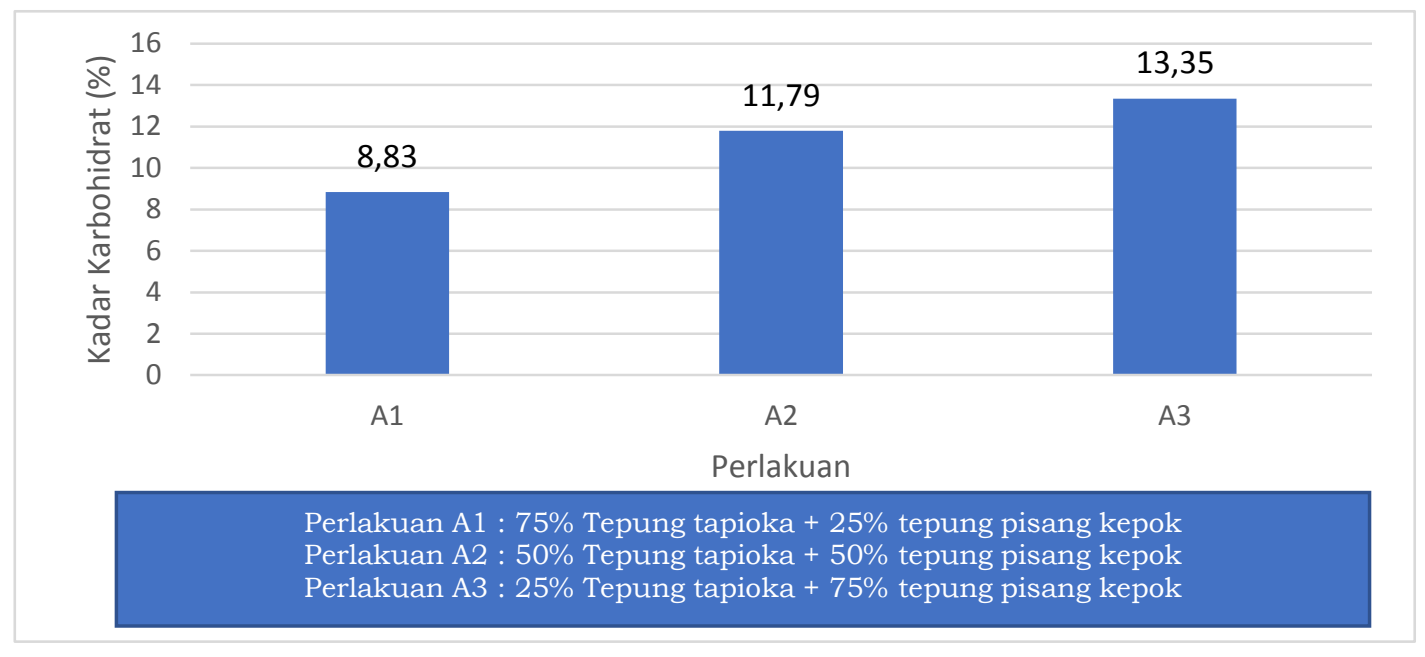

Gambar 1. Diagram Batang Kadar Karbohidrat pada Kerupuk Tepung Pisang Kepok 
Pada Gambar 3 terlihat semakin banyak penambahan tepung pisang, maka semakin tinggi kandungan karbohidrat dari kerupuk. Hal ini disebabkan kadar karnohidrat yang lebih tinggi dibandingkan tepung terigu. Hal ini sesuai dengan pendapat Suryani dan Ekawati (2013), bahwa kadar karbohidrat pisang relatif lebih tinggi ialah sebesar 70,48\% dibandingkan kadar karbohidrat tepung terigu sebesar 53,48\%. Menurut Winarno (1997), karbohidrat juga berperan dalam menentukan karateristik bahan makanan, misalnya rasa, warna, dan tekstur.

\subsection{Kadar Air}

Kadar air sangat mempengaruhi daya tahan kerupuk. Kadar air yang tinggi akan mengakibatkan mudahnya bakteri dan jamur serta mikroba lainnya untuk berkembang biak sehingga akan mempengaruhi mutu dari produk tersebut. Hasil pengukuran kadar air kerupuk pisang kepok yang dihasilkan berkisar antara 6,73\%-8,48\%. Kadar air terrendah pada kerupuk tepung pisang kepok dengan formulasi tepung tapioka $25 \%$ dan $75 \%$ tepung pisang kepok sebesar $6,73 \%$, sedangkan kadar air tertinggi pada perlakuan formulasi $25 \%$ tepung tapioka dan $75 \%$ tepung pisang kepok.

Pada diagram dibawah terlihat bahwa semakin banyak penambahan tepung pisang, maka semakin sedikit kadar air. Hal ini disesbakna karena kandungan amilosa dari tepung pisang yang jauh lebih sedikit dibandingkan tepung tapioka. Amilosa merupakan salah satu kandungan pati yang bersifat menyerap air, sehingga semakin sedikit kandungan amilosa maka semakin sedikit kandungan air dari suatu bahan. Hal ini sesuai dengan pendapat Breemer et.al (2010), amilosa yang mengalami pemanasan dengan keberadaan cukup banyak air, menyebabkan pati yang terkandung dalam tepung akan menyerap air dan membentuk pasta yang kental dan pada saat dingin membentuk masa yang kenyal, lenting dan liat.

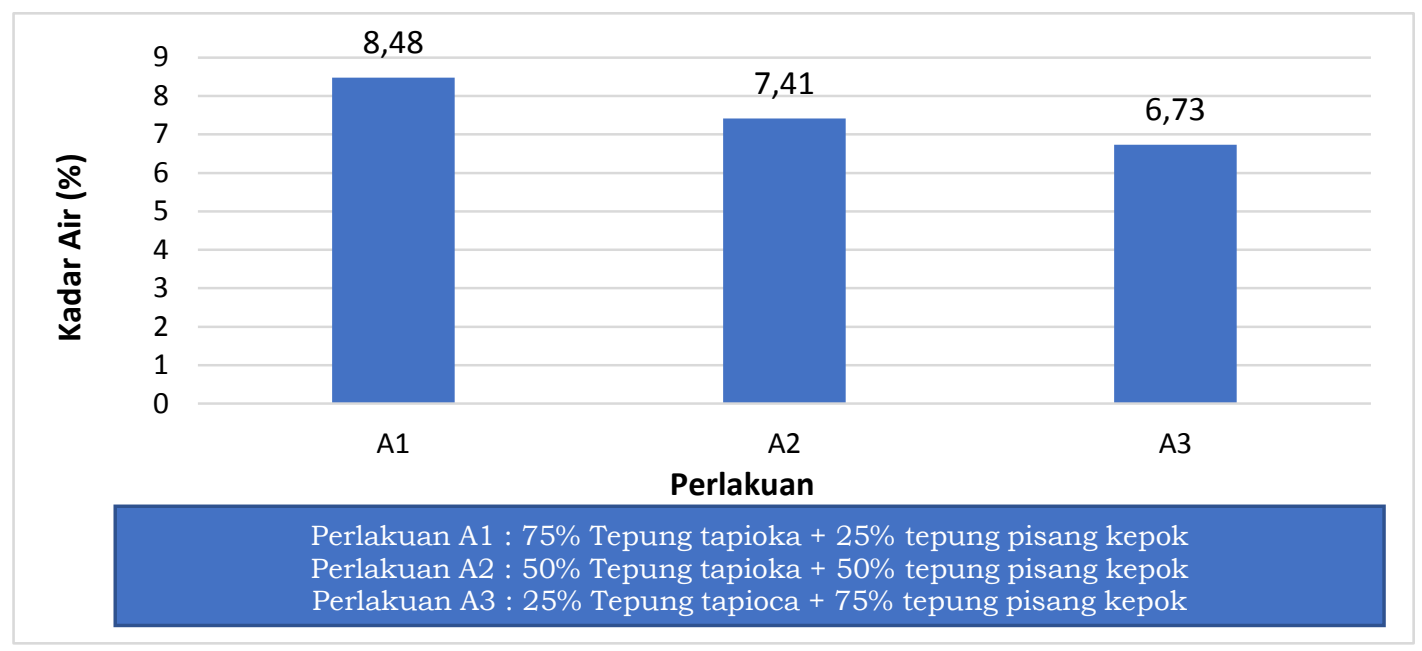

Gambar 2. Diagram Batang Kadar Air pada Kerupuk Tepung Pisang Kepok

\subsection{Kadar Abu}

Hasil pengukuran kadar abu kerupuk pisang kepok yang dihasilkan berkisar antara 1,85\% -2,42\%. Kadar abu terrendah pada kerupuk tepung pisang kepok dengan formulasi tepung tapioka 25\% dan $75 \%$ tepung pisang 
kepok sebesar 1,85\%, sedangkan kadar abu tertinggi pada perlakuan formulasi $25 \%$ tepung tapioka dan $75 \%$ tepung pisang kepok sebesar 2,42\%.

Pada Gambar 3 memperlihatkan semakin banyak penambahan tepung pisang, maka semakin banyak kadar abu dari kerupuk. Hal ini disebabkan kandungan mineral yang lebih tinggi pada tepung pisang dibandingkan tepung terigu. Hal ini sesuai dengan pendapat Suryani dan Ekawaty (2013) bahwa yang kadar abu tepung pisang berkisang 3,2\% dan kadar abu tepung terigu berkisar $1,3 \%$.

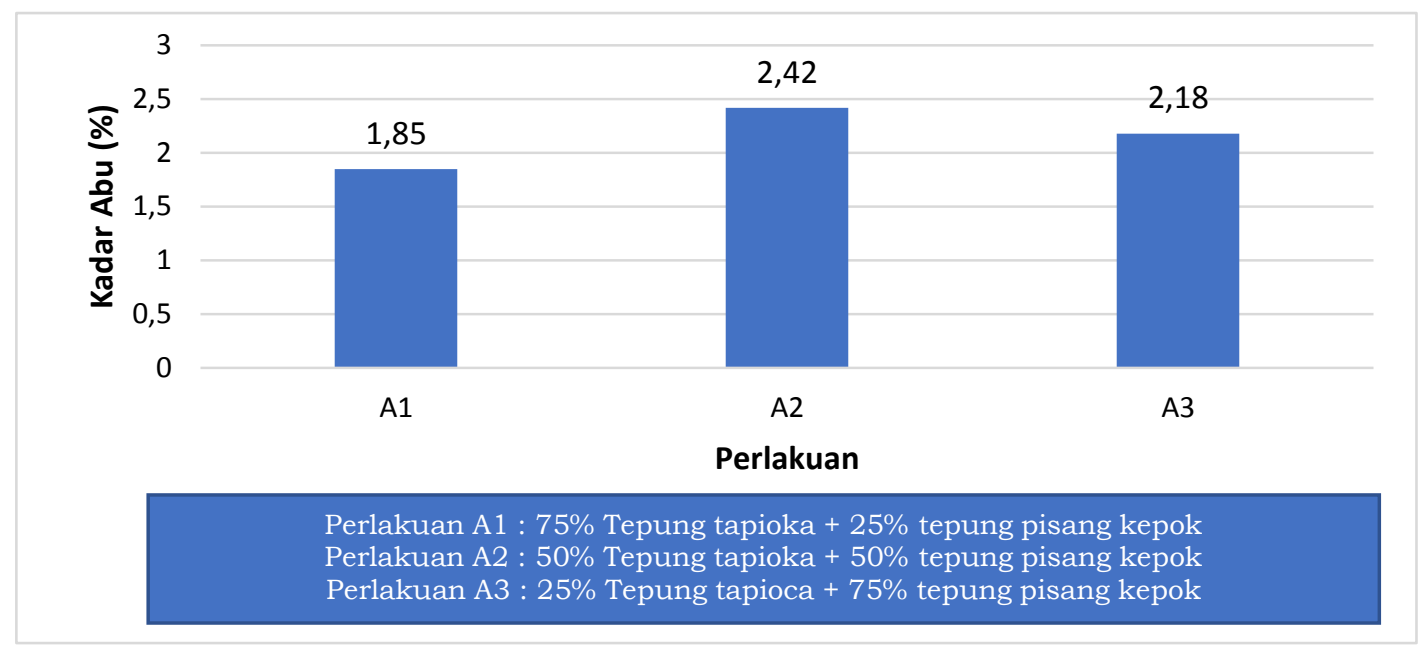

Gambar 3. Diagram Batang Kadar Abu pada Kerupuk Tepung Pisang Kepok

\subsection{Organoleptik Warna}

Warna pada makanan dapat disebabkan oleh beberapa sumber diantaranya pigmen, pengaruh panas pada gula (karamel), adanya reaksi antara gula dan asam amino (Maillard), dan adanya pencampuran bahan lain (Winarno, 1997).

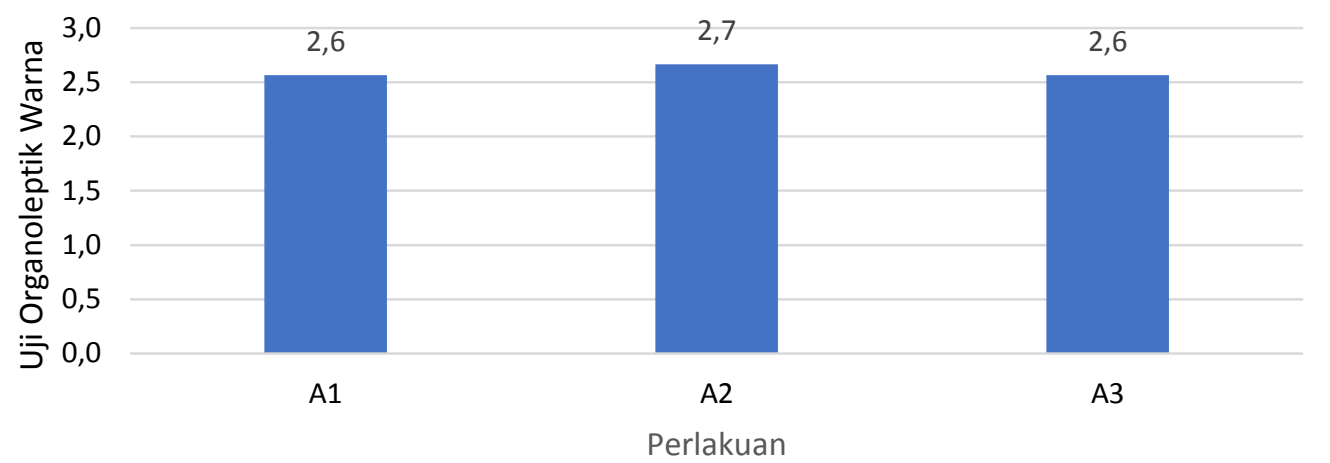

Perlakuan A1 : 75\% Tepung tapioka $+25 \%$ tepung pisang kepok Perlakuan A2 : 50\% Tepung tapioka $+50 \%$ tepung pisang kepok Perlakuan A3 : 25\% Tepung tapioca $+75 \%$ tepung pisang kepok

Gambar 4. Diagram Batang Uji Hedonik Warna pada Kerupuk Tepung Pisang Kepok

Pada gambar diatas terlihat, skor penilaian panelis terhadap warna kerupuk yang dihasilkan dari berbagai perlakuan. Pada perlakuan A1 (75\% tepung tapioka+25\% tepung pisang kepok) memiliki skor 2,6 (agak suka), 
perlakuan A2 (50\% tepung tapioka $+50 \%$ tepung pisang kepok) memiliki skor 2,7 (agak suka), sedangkan perlakuan A3 (25\% tepung tapioka $+75 \%$ tepung pisang) memiliki skor 2,6 (agak suka). Secara keseluruhan warna yang dihasilkan dari kerupuk agak disukai oleh panelis. Hal ini disebabkan karena warna yang dihasilkan dari penggorengan adalah warna coklat. Warna coklat dari kerupuk merupakan akibat dari reaksi maillard. Reaksi maillard adalah reaksi antara karbohidrat dan asam amino yang menyebabkan warna coklat. Hal ini sesuai dengan pendapat Lusia et.al., (2013), bahwa reaksi Maillard merupakan reaksi nilai rata-rata tingat kesukaan terhadap warna crackers perlakuan antara gula pereduksi dengan protein (asam amino). Hasil reaksi tersebut menghasilkan bahan berwarna coklat.

\subsection{Organoleptik Rasa}

Rasa merupakan sensasi yang diproduksi oleh material yang dimasukkan ke dalam mulut, dirasakan prinsipnya oleh indera perasa dalam mulut. Menurut Winarno (2004) rasa dipengaruhi oleh beberapa faktor yaitu senyawa kimia, suhu, konsentrasi dan interaksi dengan komponen rasa lain yaitu komponen rasa primer. Akibat yang ditimbulkan mungkin peningkatan intensitas rasa atau penurunan intensitas rasa.

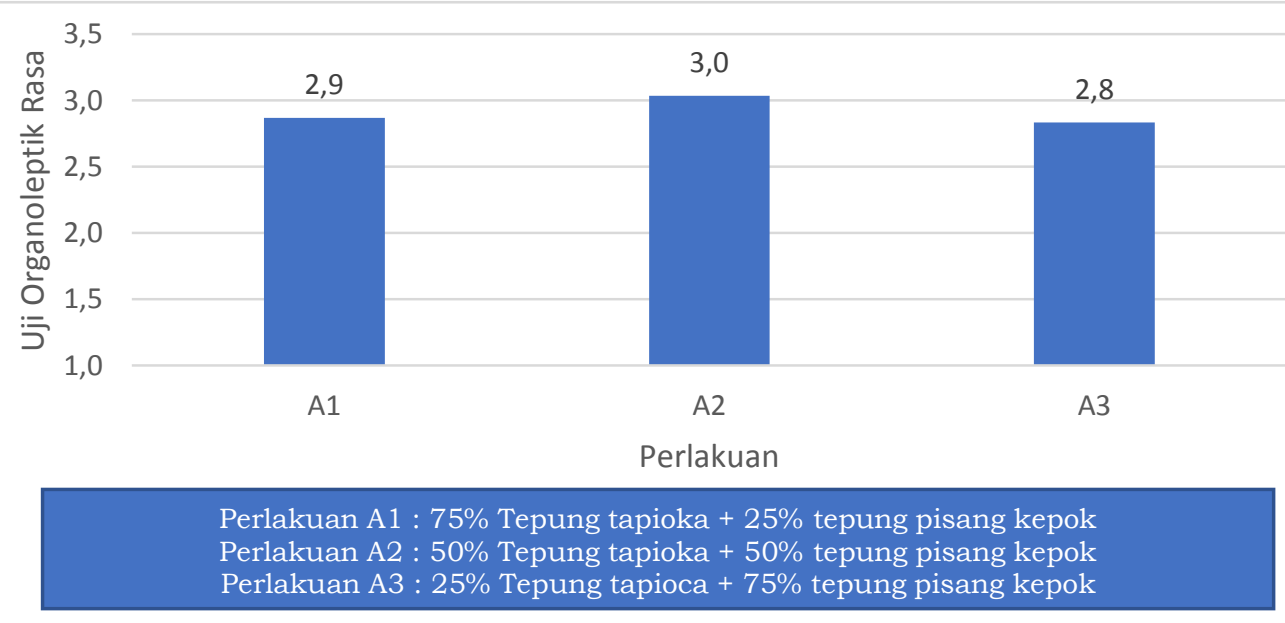

Gambar 5. Diagram Batang Uji Hedonik Rasa pada Kerupuk Tepung Pisang Kepok

Pada gambar diatas terlihat, skor penilaian panelis terhadap warna kerupuk yang dihasilkan dari berbagai perlakuan. Pada perlakuan A1 (75\% tepung tapioka+25\% tepung pisang kepok) memiliki skor 2,9 (agak suka), perlakuan A2 (50\% tepung tapioka $+50 \%$ tepung pisang kepok) memiliki skor 3,0 (suka), sedangkan perlakuan A3 (25\% tepung tapioka $+75 \%$ tepung pisang) memiliki skor 2,8 (agak suka). Terlihat perlakuan yang paling disukai oleh panelis ada perlakuan A2. Hal ini disebabkan karena seimbangnya formulasi dari tepung tapioka dan tepung pisang sehingga memiliki rasa yang disukai oleh panelis.

Menurut Winarno (2008) rasa berbeda dengan bau dan lebih banyak melibatkan panca indra lidah. Pengindraan cecapan dapat dibagi menjadi empat cecapan utama yaitu asin, asam, manis dan pahit. Perubahan tekstur atau vikositas bahan pangan dapat mengubah rasa yang timbul. Rasa yang terdeteksi dikarenakan respon terhadap sistem saraf dikenal dengan respon 
chemestheti. Rasa adalah sensasi yang timbul dari gabungan sel-sel reseptor rasa khusus yang terletak dimulut, terutama pada organ perasa (lidah), dan dipecah menjadi sensasi manis, asam, asin, pahit dan gurih atau umami ( Estiasi et.al., 2015).

\subsection{Organoleptik Aroma}

Aroma merupakan faktor penting dalam menentukan tingkat penerimaan konsumen pada suatu bahan, aroma banyak menentukan kelezatan bahan makanan, biasanya seseorang dapat menilai lezat tidaknya suatu bahan makanan dari aroma yang diimbulkan.

Pada gambar dibawah terlihat, skor penilaian panelis terhadap warna kerupuk yang dihasilkan dari berbagai perlakuan. Pada perlakuan A1 $(75 \%$ tepung tapioka+25\% tepung pisang kepok) memiliki skor 2,8 (agak suka), perlakuan A2 (50\% tepung tapioka+50\% tepung pisang kepok) memiliki skor 2,8 (suka), sedangkan perlakuan A3 (25\% tepung tapioka+75\% tepung pisang) memiliki skor 2,8 (agak suka). Terlihat perlakuan yang paling disukai oleh panelis adalah perlakuan A2. Hal ini disebabkan karena seimbangnya formulasi dari tepung tapioka dan tepung pisang sehingga memiliki aroma yang disukai oleh panelis. Aroma yang muncul tidak khas pisang ataupun khas dari tepung tapioka.

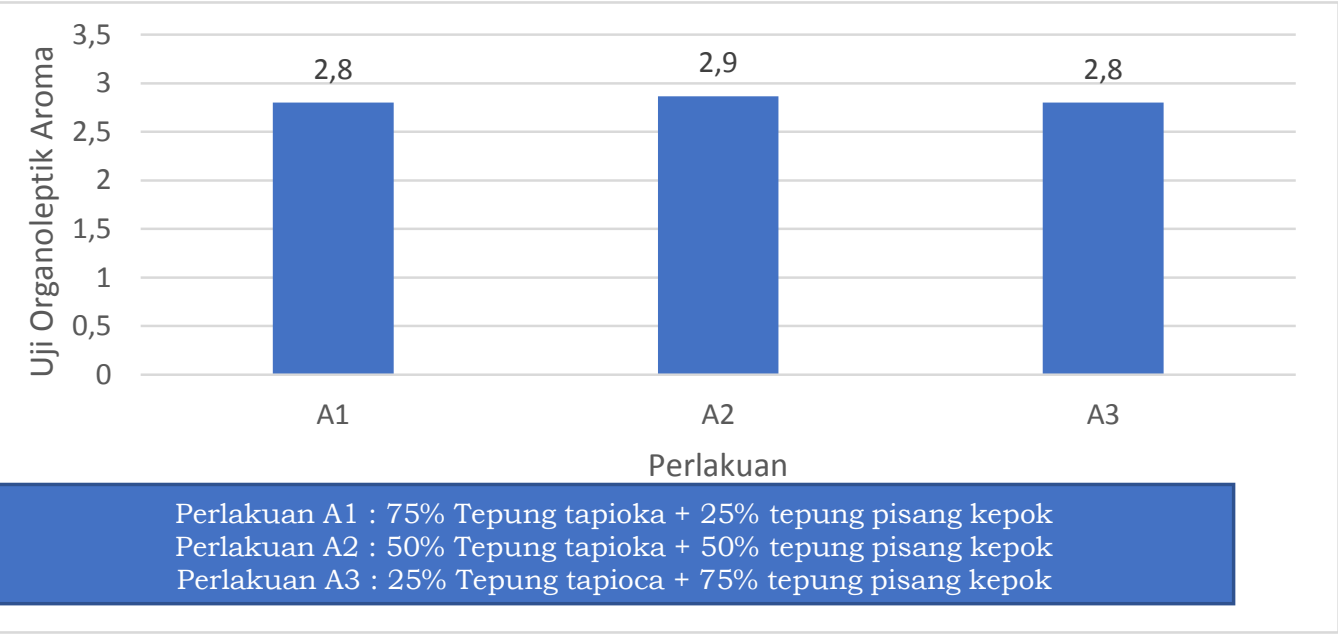

Gambar 6. Diagram Batang Uji Hedonik Aroma pada Kerupuk Tepung Pisang Kepok

Menurut Winarno (2008) bau makanan banyak menetukan bahan makanan tersebut, hal ini sesuai yang dinyatakan (Estiasih et.al., 2015) bahwa Aroma adalah komponen sensorik yang dihasikan dari interaksi komponen pangan volatile dengan reseptor penciuman di rongga hidung dan biasanya adalah aroma atau bau makanan.

\subsection{Organoleptik Tekstur}

Tekstur suatau bahan pangan merupakan salah satu sifat bahan pangan yan penting. Tekstur bahan pangan dapat diketahui dengan meenyentuh,menekan atau merabah langsung suatu produk. Disintegrasi dan aliran dari bahan pangan tekanan yang diukur secara obyektif oleh fungsi masa, waktu dan jarak (De man 1997). 


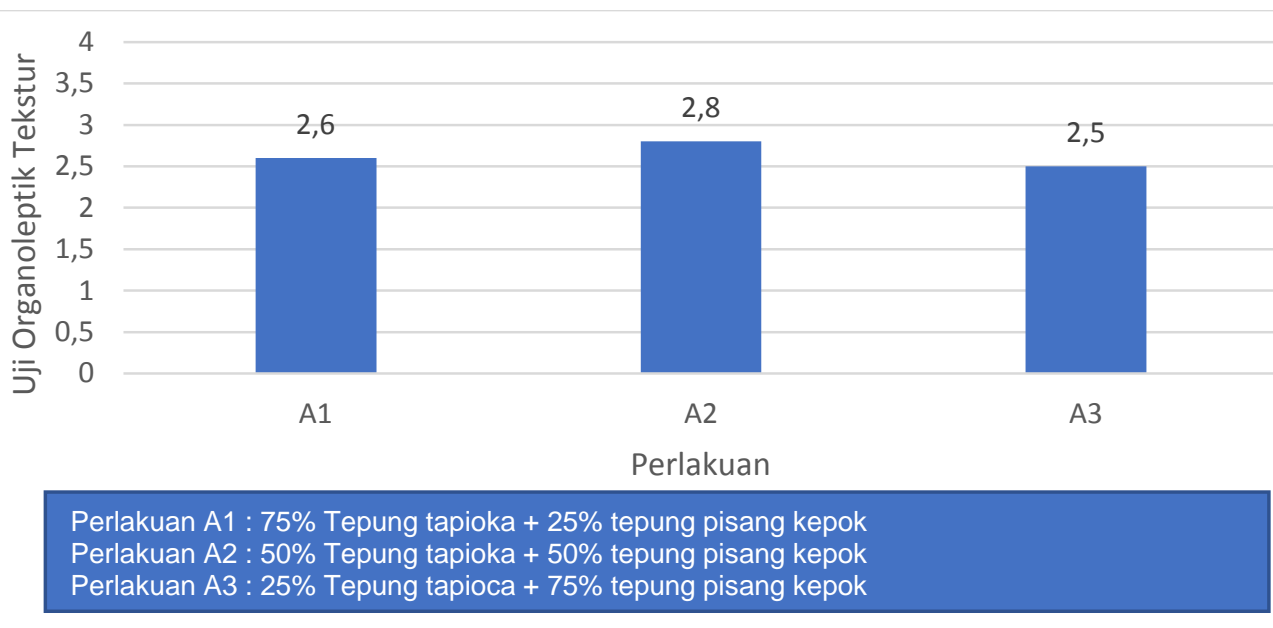

Gambar 7. Diagram Batang Uji Hedonik Tesktur pada Kerupuk Tepung Pisang Kepok

Pada gambar diatas terlihat, skor penilaian panelis terhadap warna kerupuk yang dihasilkan dari berbagai perlakuan. Pada perlakuan A1 (75\% tepung tapioka+25\% tepung pisang kepok) memiliki skor 2,6 (agak suka), perlakuan A2 (50\% tepung tapioka $+50 \%$ tepung pisang kepok) memiliki skor 2,8 (suka), sedangkan perlakuan A3 (25\% tepung tapioka $+75 \%$ tepung pisang) memiliki skor 2,5 (agak suka). Terlihat perlakuan yang paling disukai oleh panelis adalah perlakuan A2. Hal ini disebabkan karena seimbangnya formulasi dari tepung tapioka dan tepung pisang, sehingga menghasilkan tekstur yang agak disukai oleh konsumen.

\section{KESIMPULAN DAN SARAN}

\subsection{Kesimpulan}

1. Kadar air yang tertinggi adalah perlakuan A1 (75\% tepung tapioka+ $25 \%$ tepung pisang kepok) dengan nilai 8,48\%

2. Kadar abu yang tertinggi adalah perlakuan A2 (50\% tepung tapioka $+50 \%$ tepung pisang kepok) dengan nilai 2,42\%

3. Kadar karbohidrat yang tertinggi adalah perlakuan A3 (25\% tepung tapioka $+75 \%$ tepung pisang kepok) dengan nilai $13,35 \%$

4. Berdasarkan uji organoleptik, perlakuan yang terbaik adalah perlakuan A2 (50\% tepung tapioka $+50 \%$ tepung pisang kepok) dengan skor aroma 2,9 (agak suka), rasa 3,0 (suka), tekstur 2,8 ( agak suka) dan warna 2,7 (agak suka)

\subsection{Saran}

Sebaiknya dalam penelitian berikutnya dilanjutkan dengan masa simpan dari kerupuk tepung pisang kepok yang dihasilkan.

\section{REFERENSI}

Breemer, Polnaya dan Rumarupute. 2010. Pengaruh Konsentrasi Tepung

Beras Ketan Terhadap Mutu Dodol Pala. Jurnal Budidaya Pertanian, Vol. 6. No 1 Juli 2010, Halaman 17-20. 
Lusia, Djana dan Larkasi. Pengujian Organoleptik Crackers Berbahan Baku Tepung Pisang "Mulu Bebe" Indegenous Halmahera Utara. Jurnal Teknologi Dan Industri Pangan. Vol XX No.1 Th.2009.

Satuhu, S., Supriyadi A. 1994. Budidaya Pengolahan dan Prospek Pisang. Penebar Swadaya. Jakarta.

Suryani dan Ekawaty. 2013. Kualitas Non Flaky Crackers Coklat Dengan Variasi Substitusi Tepung Pisang Kepok Kuning (Musa Paradisiaca Forma Typica). Jurnal Litbang Pertanian 31(2) : 4-8.

Triyono, Agus. 2010. Pengaruh Konsentrasi Ragi Terhadap Karakteristik Sari Buah Dari Beberapa Varietas Pisang (Musa paradisiacal L). Prosiding Seminar Nasional Teknik Kimia "Kejuangan" Pengembangan Teknologi Kimia untuk Pengolahan Sumber Daya Alam Indonesia. Yogyakarta.

Winarno, F.G. 1997. Kimia Pangan dan Gizi. Gramedia Pustaka Utama. Jakarta. 